OPEN ACCESS

Edited by:

Patricio López-Jaramillo,

Fundacion Oftalmologica de

Santander - FOSCAL, Colombia

Reviewed by:

Utpal S. Bhalala,

Baylor College of Medicine

United States

Yuan Shi,

Children's Hospital of Chongqing

Medical University, China

*Correspondence:

Jiujun $\mathrm{Li}$

lijj@sj-hospital.org

Specialty section:

This article was submitted to

Children and Health,

a section of the journal

Frontiers in Pediatrics

Received: 18 March 2020

Accepted: 26 October 2020

Published: 23 November 2020

Citation:

Yu M, Liu X and Li J (2020) Factors

Influencing Vitamin D Levels in Neonatal Umbilical Cord Blood: A Two-Center Study From Tibet and

Shenyang. Front. Pediatr. 8:543719.

doi: 10.3389/fped.2020.543719

\section{Factors Influencing Vitamin D Levels in Neonatal Umbilical Cord Blood: A Two-Center Study From Tibet and Shenyang}

\author{
Mingli Y $u^{1}$, Xiuxiu Liu ${ }^{2}$ and Jiujun $L i^{1,3 *}$ \\ ${ }^{1}$ Department of Pediatrics, Shengiing Hospital of China Medical University, Shenyang, China, ${ }^{2}$ Department of Pediatrics, \\ Naqu People's Hospital, Naqu, China, ${ }^{3}$ Plateau Medical Research Center of China Medical University, Department of \\ Pediatrics, Shengjing Hospital of China Medical University, Shenyang, China
}

Objective: To investigate the factors influencing the levels of vitamin $D$ (vitD) in the umbilical cord blood of neonates born in Naqu, Tibet (4,500 m above sea level), and Shenyang, Liaoning Province (500 $\mathrm{m}$ above sea level).

Methods: This prospective study was conducted from June 2017 to October 2018 in Naqu (the plateau group) and Shenyang, (the non-plateau group). Healthy mothers that gave birth to healthy neonates of $>2,000 \mathrm{~g}$ after 38 weeks' gestation were enrolled in the study, as were their neonates. After separation of serum from the umbilical cord and mothers for routine biochemical tests, discarded samples were remained for analyses of vitD, calcium, phosphorus, alkaline phosphatase (ALP) and parathyroid hormone (PTH). Questionnaires were developed covering the demographic characteristics and possible risk factors for neonatal vitD deficiency of mothers. Statistical analysis was performed to identify associations between the calcium, phosphorus, ALP, PTH, maternal factors and neonatal vitD levels.

Results: In total, 295 neonates and 225 mothers were enrolled in the study. VitD deficiency was common in neonates and mothers. The risk of vitD deficiency was higher in the plateau group than in the non-plateau group. The mean levels of 25-hydroxy vitD $(25(\mathrm{OH}) \mathrm{D})$ in mothers and neonates from the plateau group were $8.49 \pm 4.12 \mathrm{ng} / \mathrm{mL}$ and $10.17 \pm 5.07 \mathrm{ng} / \mathrm{mL}$, respectively. Such levels were significantly lower than those in the non-plateau group $(19.77 \pm 9.57 \mathrm{ng} / \mathrm{mL}$ and $23.93 \pm 11.01 \mathrm{ng} / \mathrm{mL}$, respectively). The vitD levels of neonates and mothers were highest in the summer and lowest in the winter. Cord blood vitD was positively correlated with the vitD levels in mothers' serum ( $r$ $=0.75, P<0.05)$. Increased PTH levels in mothers and decreased cord blood calcium levels were risk factors for neonatal vitD deficiency. A lack of vitD supplementation during pregnancy was associated with an 8.91-fold higher probability of neonatal vitD deficiency $(\mathrm{OR}=8.91,95 \% \mathrm{Cl}=1.521-9.429, P<0.001)$.

Conclusions: The levels of neonatal and maternal vitD in the plateau group were generally lower than those in the non-plateau group. VitD supplementation during pregnancy could effectively reduce the risk of vitD deficiency in neonates.

Keywords: vitD deficiency, neonates, mothers, vitD supplementation, high altitude 


\section{INTRODUCTION}

VitD is not only an important steroid hormone, but also a lipidsoluble vitamin, which has a wide range of biological effects, including regulatory effects on embryonic organ development, cell proliferation, differentiation, and maturation (1). A lack of vitD during pregnancy is the most important risk factor for infantile rickets, and may also result in poor fetal growth and neonatal development (2). Although the VitD supplementation to pregnant women is encouraged by numerous published guidelines for its prevention $(3,4)$, sunlight-produced VitD in the skin has played a critically important role (5) and the altitude has a dramatic influence on previtamin $\mathrm{D}_{3}$ synthesis as well (6). When an adult wearing a bathing suit is exposed to one minimal erythemal dose of ultroviole radiation (a slight pinkness to the skin $24 \mathrm{~h}$ after exposure), the amount of vitamin $\mathrm{D}$ produced is equivalent to ingesting between 10,000 and 25,000 IU (7). Low exposure to sun, atmospheric pollution, low physical activity, indoor confinement during the day and high buildings are common risk factors of VitD deficiency in the pregnant women (8). These risk factors are infrequent at high altitudes regions as compared to plain areas. Nevertheless, VitD deficiency occurs mostly in higher altitudes (9). The prevalence of vitD deficiency during pregnancy and in neonates at high altitude $(1,900-2,200 \mathrm{~m}$ above sea level) is higher than those in plains (10). Among nomads in Tibet $(4,500 \mathrm{~m}$ above sea level), the $25(\mathrm{OH}) \mathrm{D}$ status is alarmingly low (11). Besides, the pregnancy alone increases the risk of vitamin D deficiency $(8,12)$.

There is no investigation on the vitD status among pregnant women and neonates from Tibet, the ultrahigh-altitude region. Nor have there been large-scale national survey data to report the vitD status of neonates in China. This study investigated the demographic characteristics and possible risk factors that may affect the levels of vitD, as well as tested the levels of $25(\mathrm{OH}) \mathrm{D}$, calcium, phosphorus, ALP, and PTH in umbilical cord blood and pregnant women living in ultrahigh-altitude regions (Naqu, Tibet, $4,500 \mathrm{~m}$ above sea level) and the plain (Shenyang, Liaoning, $500 \mathrm{~m}$ above sea level). Using such data, our study aimed to fill the knowledge gap of maternal and neonatal vitD status in the ultrahigh-altitude region, as well as explore the correlation of maternal-neonatal pairs with vitD levels. Moreover, the results from regional studies are critical to develop appropriate prevention strategies during pregnancy, to optimize vitamin $\mathrm{D}$ status of mothers and neonates, in a region-specific manner.

\section{METHODS AND MATERIALS}

\section{Subjects}

From June 2017 to October 2018, our study recruited 225 mothers and 295 neonates delivered at the Naqu People's Hospital, Tibet (the plateau group) and the Shengjing Hospital of China Medical University, Shenyang (the non-plateau group). Healthy mothers who gave birth to healthy neonates weighing $>2,000 \mathrm{~g}$ after 38 weeks' gestation were included, as were their neonates. Neonates with genetic metabolic diseases, infections, asphyxia, anemia, and intrauterine growth restriction, or those who were born premature were excluded from the study. Mothers with an infection during pregnancy and those who had an early membrane rupture, chorioamnionitis, preeclampsia, hypertension, gestational diabetes, chronic diarrhea, liver diseases, kidney diseases, parathyroid diseases, and other calcium-modifying conditions were also excluded. The study was approved by the Ethics Committee of the Shengjing Hospital of China Medical University (Protocol Identification Number: 2017PS33K).

\section{Sample Collection}

When the pregnant women are hospitalized for labor (within 3 days before delivery), $2 \mathrm{~mL}$ of venous blood for biochemical tests is taken routinely. It is difficult to collect blood from neonates, thus the samples for blood gas ion analysis and biochemical tests for neonates are from umbilical cord immediately following birth. After the separation of serum for biochemical tests, the remaining serum is retained in the test center. The samples used in our study were all discarded samples after the clinical routine diagnosis and treatment, which had no impact on the routine diagnosis and treatment of patients, and stored at $-80^{\circ} \mathrm{C}$ until analysis at the Clinical Test Center of Shengjing Hospital. Samples from Naqu were sent to the same laboratory by the Cold-chain transportation. The gestational age, birth weight, body length, head circumference, and chest circumference of neonates were measured and recorded, as was the age, gestational times, delivery times, and the details of vitD supplementation for mothers.

Serum 25(OH)D levels were analyzed by an electrochemiluminescence immunoassay (competitive inhibition method) using the Roche E602 device. Serum PTH was also analyzed by electrochemiluminescence immunoassays (double antibody sandwich method) using the Roche E602 device. Serum calcium was detected using the methyl dimethyl phenol blue (MXB) method, phosphorus was detected using the molybdate method (UV absorption method of phosphomolybdic acid), and ALP was detected using the $P$-nitrobenzene method of phosphoric acid using with the Abbott I16200 device. Adult reference ranges are calcium (1.9-2.6 $\mathrm{mmol} / \mathrm{L})$, phosphate (1.2-1.9 mmol/L), ALP (40-375 U/L), and PTH (15-65 pg/mL).

\section{Identification of 25(OH)D Levels}

A cord blood serum 25(OH)D level $<12 \mathrm{ng} / \mathrm{mL}$ (30 nmol/L) was considered as vitD deficiency, $12-20 \mathrm{ng} / \mathrm{mL}(30-50 \mathrm{nmol} / \mathrm{L})$ was considered as vitD insufficiency, and $>20 \mathrm{ng} / \mathrm{mL}(50 \mathrm{nmol} / \mathrm{L})$ was considered as vitD sufficiency (13). In pregnant women, vitD deficiency was defined as a $25(\mathrm{OH}) \mathrm{D}$ level below $20 \mathrm{ng} / \mathrm{mL}(50$ $\mathrm{nmol} / \mathrm{L})$, while vitD insufficiency was defined as a $25(\mathrm{OH}) \mathrm{D}$ level of $21-29 \mathrm{ng} / \mathrm{mL}(52.5-72.5 \mathrm{nmol} / \mathrm{L})(4)$.

\section{Statistical Analysis}

SPSS 23.0 (SPSS, Chicago, IL, USA) was used for the processing and statistical analysis of the data. Numeric data were shown as the mean and standard deviation. Categorical data were summarized as number and percentage. The Mann-Whitney $U$ test and Kruskal-Wallis test were used for statistical analyses of non-parametric data. Parametric variables were analyzed 
TABLE 1 | Baseline characteristics between the plateau and non-plateau groups.

\begin{tabular}{lcccc}
\hline & Plateau & Non-plateau & $\boldsymbol{t} / \boldsymbol{\chi}^{2}$-value & $\boldsymbol{P}$ \\
\hline Neonatal BMl (kg/m²) & $12.97 \pm 1.74$ & $13.07 \pm 1.53$ & -6.811 & 0.093 \\
gestational age (week) & $39.64 \pm 0.87$ & $39.78 \pm 0.82$ & -0.628 & 0.531 \\
Gender (male/female) & $26 / 21$ & $121 / 127$ & 0.674 & 0.412 \\
Medical insurance (yes/no) & $45 / 2$ & $238 / 10$ & 0.005 & 0.943 \\
Mothers age & $28.85 \pm 5.06$ & $29.34 \pm 4.23$ & -3.222 & 0.101 \\
Gestational times & $3.03 \pm 1.48$ & $1.72 \pm 0.84$ & 9.692 & 0.245 \\
Delivery times & $2.58 \pm 1.12$ & $1.57 \pm 0.59$ & 15.677 & 0.216 \\
\hline
\end{tabular}

BMI for Body Mass Index.

using Student's $t$-tests and one-way analysis of variance. Unitary linear regression analysis was used to determine the association between each potential risk factor and serum 25(OH)D levels. Binary logistic regression analysis was used to calculate the odds ratios (OR) concerning vitD deficiency. A $P$-value of 0.05 was considered statistically significant.

\section{RESULTS}

\section{General Information}

There were 295 umbilical cord blood samples collected and 225 were paired with maternal samples. A total of 47 neonates (26 males; 21 females) and 47 mothers were included from the Naqu People's Hospital of Tibet, which formed the plateau group, and 248 neonates (121 males; 127 females) and 178 mothers were included from the Shengjing Hospital of China Medical University, Shenyang, Liaoning Province, which formed the non-plateau group. Among the 295 neonates, the average gestational age was $39.70 \pm 0.83$ weeks (range, 38-41.29 weeks), and the average birth weight was 3,319.85 $\pm 397.36 \mathrm{~g}$ (range, 2,100-4,475 g). Maternal and neonatal characteristics according to either regional group are shown in Table 1. There was no significant difference in the baseline characteristics between the plateau and non-plateau groups.

Among the 47 neonates in the plateau group, $39(82.98 \%)$ exhibited 25(OH)D levels below $12 \mathrm{ng} / \mathrm{mL}$, while seven $(14.89 \%)$ exhibited 25(OH)D levels between $12-20 \mathrm{ng} / \mathrm{mL}$, and only one (2.13\%) exhibited a level above $20 \mathrm{ng} / \mathrm{mL}$. Among the 248 neonates from the non-plateau group, 51 (20.56\%) exhibited 25(OH)D levels below $12 \mathrm{ng} / \mathrm{mL}$, while 91 (36.69\%) exhibited 25(OH)D levels between 12-20 ng/mL, and 106 (42.75\%) had $25(\mathrm{OH}) \mathrm{D}$ levels above $20 \mathrm{ng} / \mathrm{mL}$. The average cord blood $25(\mathrm{OH}) \mathrm{D}$ level in the plateau group was $8.49 \pm 4.12 \mathrm{ng} / \mathrm{mL}$, which was significantly lower than that in the non-plateau group (19.77 $\pm 9.57 \mathrm{ng} / \mathrm{mL})$. A statistically significant difference was observed in vitD levels from neonatal cord blood samples between the plateau and the non-plateau groups $(P<0.05)$. Among the 47 mothers in the plateau group, $44(93.62 \%)$ exhibited 25(OH)D levels below $12 \mathrm{ng} / \mathrm{mL}$, while three $(6.38 \%)$ exhibited 25(OH)D levels between $12-20 \mathrm{ng} / \mathrm{mL}$, and none had levels above $20 \mathrm{ng} / \mathrm{mL}$. The average 25(OH)D level was $10.17 \pm$ $5.07 \mathrm{ng} / \mathrm{mL}$. As for the 178 mothers in the non-plateau group, $24(13.48 \%)$ exhibited 25(OH)D levels below $12 \mathrm{ng} / \mathrm{mL}$, while 53
(29.78\%) exhibited 25(OH)D levels between $12-20 \mathrm{ng} / \mathrm{mL}$, and $101(56.74 \%)$ had $25(\mathrm{OH}) \mathrm{D}$ levels above $20 \mathrm{ng} / \mathrm{mL}$. The average $25(\mathrm{OH}) \mathrm{D}$ level of mothers in the non-plateau group was 23.93 $\pm 11.01 \mathrm{ng} / \mathrm{mL}$, which was significantly higher than that in the plateau group $(P<0.05$; Figure 1, Table 2$)$.

When groups were classified based on cord blood $25(\mathrm{OH}) \mathrm{D}$ levels by $20 \mathrm{ng} / \mathrm{mL}$, categorized as deficient $(<20 \mathrm{ng} / \mathrm{mL})$ and normal $(\geq 20 \mathrm{ng} / \mathrm{mL})$, there were statistically significant differences in the levels of cord blood calcium, phosphorus, ALP, and PTH between the two groups, as well as in the age, gestational times, delivery times, and PTH and vitD levels among mothers $(P$ $<0.05$; Table 3 ). In three clinically normal neonates with very low $25(\mathrm{OH}) \mathrm{D}$ status $(4.60,4.83$, and $5.18 \mathrm{ng} / \mathrm{mL}$, respectively), their calcium, phosphate and ALP were in normal range. In one $(1 / 295)$ clinically normal neonate with low $25(\mathrm{OH}) \mathrm{D}$, $10.89 \mathrm{ng} / \mathrm{mL}$, his calcium, phosphate and ALP (161.5U/L) were in normal range, except high PTH $(91.3 \mathrm{pg} / \mathrm{mL}) .98 .98 \%$ of the neonates had PTH lower than the normal adult range (15-65 $\mathrm{pg} / \mathrm{mL}$ ). However, none of the neonates had hypocalcemia. The mean values of serum calcium, phosphate, ALP, and PTH levels in mothers were within normal range. Neonates within $25(\mathrm{OH}) \mathrm{D}$ levels $<20 \mathrm{ng} / \mathrm{mL}$ had higher ALP and PTH levels compared with the normal $25(\mathrm{OH}) \mathrm{D}$ group, so as their mothers.

\section{Calcium, Phosphorus, ALP, and PTH Levels of Cord Blood in Naqu (the Plateau Group) and Shenyang (the Non-plateau Group), and Their Correlations}

The levels of umbilical cord blood phosphorus and ALP were higher in the plateau group than in the non-plateau group, while birth weight was lower in the plateau group than in the nonplateau group. The differences were statistically significant $(P$ $<0.05)$. Cord blood calcium levels were higher in the plateau group than those in the non-plateau group, while PTH levels were lower in the plateau group than in the non-plateau group. However, both differences were not statistically significant $(P>$ 0.05; Table 4).

\section{Correlations Between Components of the Calcium Metabolic System and VitD in Neonates}

There was no linear correlation between cord blood vitD levels and cord blood PTH, phosphorus, and ALP levels $(P>0.05)$. Cord blood calcium levels were positively correlated with cord blood vitD levels, but the correlation coefficient was small $(R=$ $0.185, P<0.01)$. No linear correlation was observed between cord blood PTH and cord blood calcium, phosphorus, and ALP levels $(P>0.05$; Table 5).

\section{Correlation of VitD Metabolic System Components Between Neonates and Mothers}

Cord blood vitD level was positively correlated with mothers' serum vitD level $(r=0.75, P<0.05)$ and inversely weakly correlated with mothers' gestational times, and delivery times $(r$ $=0.175,0.278$, respectively, $P<0.05$ for both). The levels of 


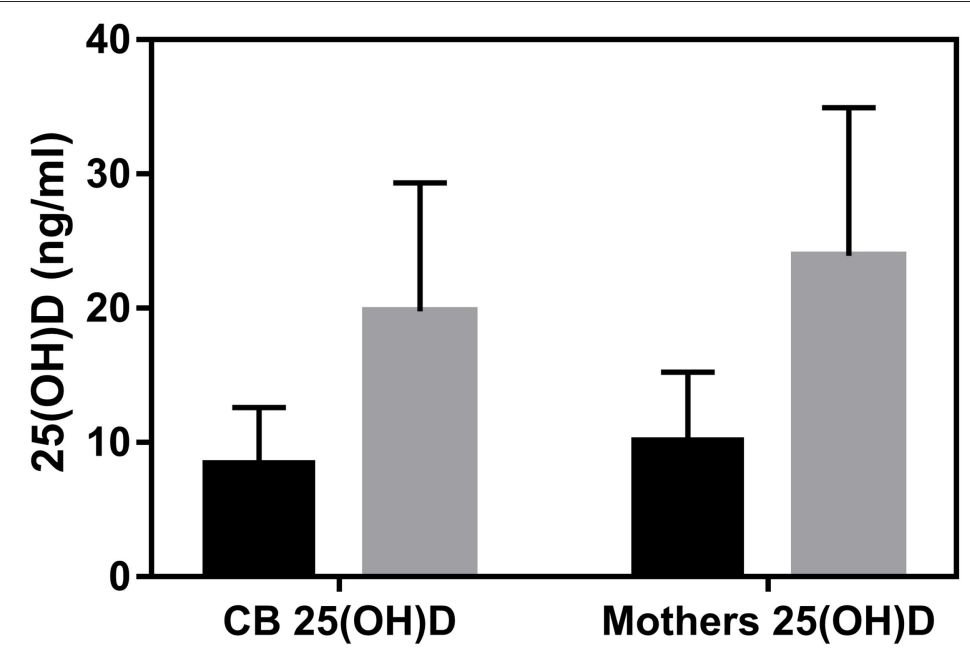

\section{Q Plateau \\ Non-plateau}

FIGURE 1 | The average 25(OH)D levels of cord blood and mothers between the plateau and non-plateau groups.

TABLE 2 | Vitamin D status of cord blood and mothers between the plateau and non-plateau groups.

\begin{tabular}{lcc}
\hline & Plateau & Non-plateau \\
\hline CB 25(OH)D ( $\leq 12 \mathrm{ng} / \mathrm{mL})$ (deficient) & $39(82.90 \%)$ & $51(20.56 \%)$ \\
CB 25(OH)D (12-20 ng/mL) (insufficient) & $7(14.90 \%)$ & $91(36.69 \%)$ \\
CB 25(OH)D $(\geq 20 \mathrm{ng} / \mathrm{ml})($ normal level) & $1(2.1 \%)$ & $106(42.75 \%)$ \\
Mothers 25(OH)D $(\leq 20 \mathrm{ng} / \mathrm{ml})($ deficient) & $44(93.62 \%)$ & $24(13.48 \%)$ \\
Mothers 25(OH)D $(20-29 \mathrm{ng} / \mathrm{ml})$ (insufficient) & $3(6.38 \%)$ & $53(29.78 \%)$ \\
Mothers 25(OH)D $(30-100 \mathrm{ng} / \mathrm{ml})$ (normal level) & 0 & $101(56.74 \%)$
\end{tabular}

CB for cord blood.

calcium and phosphorus in cord blood were positively weakly correlated with mothers' serum vitD level $(P<0.05$; Table 6). Cord blood vitD level was positively correlated with the levels of mothers' calcium, phosphorus, but inversely correlated with the levels of mothers' ALP and PTH, both weakly, $(P<0.05$; Table 6).

\section{VitD Levels of Neonates and Mothers in Different Seasons}

The blood collection time was divided into four seasons, including spring (March to May); summer (June to August); autumn (September to November); and winter (December to February). A significant seasonal difference in vitD levels was observed between cord blood and mothers' serum $(F=3.446$ and 6.890 , respectively, $P<0.05$ for both). VitD levels in cord blood and mothers' serum were highest in the summer, with mean concentrations of $22.12 \pm 7.97 \mathrm{ng} / \mathrm{mL}$ and $28.16 \pm 10.47 \mathrm{ng} / \mathrm{mL}$, respectively. Additionally, vitD levels in cord blood and mothers' serum were lowest in the winter, with mean concentrations of $17.70 \pm 6.50 \mathrm{ng} / \mathrm{mL}$ and $19.47 \pm 4.59 \mathrm{ng} / \mathrm{mL}$, respectively (Table 7).
TABLE 3 | Univariate analysis of independent factors in neonatal cord blood vitamin D.

\begin{tabular}{|c|c|c|c|c|}
\hline Variable & $\begin{array}{l}\text { CB Vitamin D } \\
\text { deficiency group } \\
(N=188)\end{array}$ & $\begin{array}{l}\text { CB Normal } \\
\text { vitamin D group } \\
(N=107)\end{array}$ & $t$ & $p$ \\
\hline Birth weight (g) & $3318.5 \pm 4375.9$ & $3322.2 \pm 3164.1$ & -0.076 & 0.067 \\
\hline $\begin{array}{l}\text { CB PTH } \\
(\mathrm{pg} / \mathrm{ml})\end{array}$ & $5.16 \pm 2.06$ & $4.27 \pm 2.60$ & -2.762 & 0.007 \\
\hline $\begin{array}{l}\text { CB phosphorus } \\
\text { (mmol/L) }\end{array}$ & $1.81 \pm 0.69$ & $1.68 \pm 0.29$ & 1.823 & 0.028 \\
\hline $\begin{array}{l}\text { CB calcium } \\
(\mathrm{mmol} / \mathrm{L})\end{array}$ & $2.25 \pm 0.42$ & $2.35 \pm 0.23$ & -2.215 & 0.001 \\
\hline $\begin{array}{l}\text { CB ALP } \\
(\cup / L)\end{array}$ & $158.88 \pm 70.67$ & $146.04 \pm 44.41$ & 1.698 & 0.001 \\
\hline Mothers age & $29.34 \pm 4.26$ & $29.85 \pm 3.29$ & -1.081 & 0.010 \\
\hline Gestational times & $1.90 \pm 0.67$ & $1.54 \pm 0.62$ & 2.644 & $<0.001$ \\
\hline Delivery times & $1.64 \pm 0.51$ & $1.18 \pm 0.45$ & 3.837 & $<0.001$ \\
\hline $\begin{array}{l}\text { Mothers 25(OH)D } \\
\text { (ng/mL) }\end{array}$ & $15.30 \pm 7.03$ & $29.86 \pm 12.46$ & -10.666 & $<0.001$ \\
\hline $\begin{array}{l}\text { Mothers PTH } \\
(\mathrm{pg} / \mathrm{mL})\end{array}$ & $23.26 \pm 10.85$ & $18.11 \pm 8.37$ & 3.339 & 0.001 \\
\hline $\begin{array}{l}\text { Mothers ALP } \\
(\mathrm{U} / \mathrm{L})\end{array}$ & $191.14 \pm 81.67$ & $162.81 \pm 87.50$ & 2.757 & 0.559 \\
\hline $\begin{array}{l}\text { Mothers phosphorus } \\
(\mathrm{mmol} / \mathrm{L})\end{array}$ & $1.20 \pm 0.34$ & $1.10 \pm 0.33$ & 2.325 & 0.549 \\
\hline $\begin{array}{l}\text { Mothers calcium } \\
\text { (mmol/L) }\end{array}$ & $2.19 \pm 0.14$ & $2.19 \pm 0.21$ & -0.035 & 0.136 \\
\hline
\end{tabular}

CB for cord blood; PTH for parathyroid hormone; ALP for alkaline phosphatase.

\section{The Correlations of Independent Factors With 25(OH)D Levels by Multivariate}

\section{Analysis}

There was no multicollinearity among neonatal birth weight, cord blood PTH, calcium, phosphorus, and ALP, or maternal 
TABLE 4 | 25(OH)D, calcium, phosphorus, ALP, PTH of cord blood and neonatal birth weight between the plateau and non-plateau groups.

\begin{tabular}{|c|c|c|c|c|c|}
\hline & Calcium (mmol/L) & Phosphorus (mmol/L) & ALP (U/L) & $\begin{array}{c}\text { PTH } \\
\text { (pg/mL) }\end{array}$ & Birth weight (g) \\
\hline $\begin{array}{l}\text { Plateau } \\
(N=47)\end{array}$ & $2.34 \pm 0.20$ & $2.05 \pm 0.53$ & $212.04 \pm 69.78$ & $1.56 \pm 0.95$ & $2988.98 \pm 363.75$ \\
\hline $\begin{array}{l}\text { Non-plateau } \\
(N=248)\end{array}$ & $2.28 \pm 0.39$ & $1.71 \pm 0.57$ & $143.27 \pm 54.86$ & $4.82 \pm 2.36$ & $3371.34 \pm 426.78$ \\
\hline$t$ & 1.111 & 3.761 & 7.523 & -4.732 & -5.847 \\
\hline$p$ & 0.267 & $<0.01$ & $<0.01$ & 0.091 & $<0.01$ \\
\hline
\end{tabular}

PTH for parathyroid hormone; ALP for alkaline phosphatase.

TABLE 5 | Correlations between components of the calcium metabolic system and vitamin $\mathrm{D}$ in cord blood.

\begin{tabular}{lccccc}
\hline & & 25(OH)D & Calcium & Phosphorus & ALP \\
\hline PTH & $R$ & -0.003 & 0.106 & -0.176 & 0.045 \\
Calcium & $P$ & 0.964 & 0.069 & 0.052 & 0.446 \\
\multirow{2}{*}{ Phosphorus } & $R$ & 0.185 & & & \\
\multirow{3}{*}{ ALP } & $P$ & 0.001 & & & \\
& $R$ & -0.096 & & & \\
& $P$ & 0.099 & & & \\
& $R$ & -0.092 & & & \\
& $P$ & 0.114 & & & \\
\hline
\end{tabular}

PTH for parathyroid hormone; ALP for alkaline phosphatase.

TABLE 6 | Correlation of vitamin D metabolic system components between mothers and cord blood.

\begin{tabular}{rccccc}
\hline & $\begin{array}{c}\text { Mothers } \\
\text { 25(OH)D }\end{array}$ & $\begin{array}{c}\text { Mothers } \\
\text { calcium }\end{array}$ & $\begin{array}{c}\text { Mothers } \\
\text { phosphorus }\end{array}$ & $\begin{array}{c}\text { Mothers } \\
\text { ALP }\end{array}$ & $\begin{array}{c}\text { Mothers } \\
\text { PTH }\end{array}$ \\
\hline $\mathrm{CB} 25(\mathrm{OH}) \mathrm{D} R$ & 0.75 & 0.134 & 0.141 & 0.127 & 0.221 \\
$P$ & $<0.001$ & 0.044 & 0.034 & 0.032 & 0.001 \\
\hline
\end{tabular}

CB for cord blood; PTH for parathyroid hormone; ALP for alkaline phosphatase.

serum vitD, PTH, calcium, phosphorus and ALP levels. There was no significant difference in the effects of maternal age, gestational times, delivery times, or PTH, ALP and phosphorus levels on cord blood vitD levels by logistic regression analysis $(P$ $>0.05$ ). Decreased cord blood calcium levels and increased PTH levels in mothers were risk factors for neonatal vitD deficiency. Mothers without vitD supplementation during pregnancy were associated with an 8.91-fold higher probability of neonatal vitD deficiency at birth $(\mathrm{OR}=8.91,95 \% \mathrm{CI}=1.521-9.429, P<0.001)$. The risk of neonatal vitD deficiency was 14.11 -fold higher for neonates born in the plateau area, compared to neonates born in the non-plateau area $(\mathrm{OR}=14.11,95 \% \mathrm{CI}=1.055-7.571, P$ $=0.015$ ).

Decreased cord blood calcium (by $1 \mathrm{mmol} / \mathrm{L}$ ) was associated with a 4.69 (1/0.213)-fold higher probability of neonatal vitD deficiency at birth $(\mathrm{OR}=0.213,95 \% \mathrm{CI}=0.069-0.660, P=$ 0.007 ). The risk of cord blood vitD deficiency decreased by $13.5 \%$ for every unit of maternal vitD increase $(\mathrm{OR}=0.881,95 \% \mathrm{CI}=$ $0.845-0.918, P<0.001)$, but increased by $5.9 \%$ for every unit of maternal PTH increase $(\mathrm{OR}=1.059,95 \% \mathrm{CI}=1.015-1.105, P=$ 0.008; Table 8).

\section{DISCUSSION}

This is the first survey of vitD levels in the umbilical cord blood of neonates and their mothers in the ultrahigh altitude $(4,500 \mathrm{~m}$ above sea level) area of Naqu, Tibet, as well as a large-scale national survey data to report the maternal and neonatal vitD status in China. Although the prevalence of vitD deficiency in mothers and neonates has been widely reported throughout the world, studies on the components of the vitD metabolism system (calcium, phosphorus, ALP, PTH) between mothers and neonates are rare. Our study included 47 pairs of mother-neonate samples from the Naqu plateau and 178 pairs of mother-neonate samples from the Shenyang non-plateau area. The level of cord blood $25(\mathrm{OH}) \mathrm{D}$ in Naqu $(8.49 \pm 4.12 \mathrm{ng} / \mathrm{mL})$ was very low. It has been reported in other regions, the values of cord blood $25(\mathrm{OH}) \mathrm{D}$ were $31.0 \pm 12.5 \mathrm{nmol} / \mathrm{L}$ in Zhejiang (14), $29.77 \pm 12.51 \mathrm{nmol} / \mathrm{L}$ in Shanghai (15), $31.58 \pm 12.72 \mathrm{ng} / \mathrm{mL}$ in Guangzhou (16) and $14.4 \pm 6.7 \mathrm{ng} / \mathrm{mL}$ in Beijing (17). Vitamin D deficiency is also common in neonates and their mothers in Europe (18) and America (19). In our study, nearly half of mothers and their neonates in the non-plateau group exhibited vitD deficiency, by contrast, that prevalence increased to $100 \%$ in mothers and $97.88 \%$ in neonates residing in the plateau. The risk of vitD deficiency in neonates born in Naqu (plateau) was significantly higher than that for neonates born in Shenyang (non-plateau area). Based on previous findings (10), the geographical location at northern hemisphere and high altitude (1,900-2,200 $\mathrm{m}$ above sea level), might have contributed to the high prevalence of neonatal and maternal hypovitaminosis D during pregnancy. It was also found in vitro ampoule experiments at Everest, the production of previtamin $\mathrm{D}_{3}$ was associated with altitude (6). $\mathrm{Naqu}$ is located at northern hemisphere and extremely high altitude, where the intensity of ultraviolet radiation is greater than that of the Shenyang non-plateau area. However, the annual average temperature is $-2.2^{\circ} \mathrm{C}$ in $\mathrm{Naqu}$, and the need for heavy traditional Tibetan clothing limits the body surface exposed to ultraviolet B radiation (UVB). Compared to pregnant women in the non-plateau area, the skin color of mothers in Naqu is darker, which is adverse for vitamin $\mathrm{D}$ synthesis. The vitD content in a traditional Tibetan diet is rare, including highland barley, wheat, beef, mutton, and ghee (11). Thus, all such factors have been 
TABLE 7 | Vitamin D levels of neonates and mothers in different seasons.

\begin{tabular}{|c|c|c|c|c|c|c|}
\hline Seasons & $\begin{array}{c}\text { Neonates } \\
\text { number }\end{array}$ & $\begin{array}{c}\text { CB } \\
\text { 25(OH)D }\end{array}$ & $F(P)$ value & $\begin{array}{l}\text { Mothers } \\
\text { number }\end{array}$ & $\begin{array}{l}\text { Mothers } \\
25(\mathrm{OH}) \mathrm{D}\end{array}$ & $F(P)$ value \\
\hline Spring & 21 & $19.00 \pm 7.37$ & $F=3.446$ & 21 & $24.44 \pm 9.21$ & $F=6.890$ \\
\hline Summer & 87 & $22.12 \pm 7.97$ & $P=0.018$ & 66 & $28.16 \pm 10.47$ & $P<0.01$ \\
\hline Autumn & 84 & $19.29 \pm 6.73$ & & 55 & $21.28 \pm 10.07$ & \\
\hline Winter & 21 & $17.70 \pm 6.50$ & & 19 & $19.47 \pm 4.59$ & \\
\hline
\end{tabular}

TABLE 8 | Multivariate analysis for factors associated with vitamin D deficiency in cord blood.

\begin{tabular}{lccccc}
\hline Variable & B & Wald $\chi^{2}$ & $\boldsymbol{P}$ & OR & 95\% CI \\
\hline Born in plateau & 2.647 & 5.864 & 0.015 & 14.11 & $1.055-7.571$ \\
Without VitD supplementation & 2.187 & 7.086 & 0.008 & 8.91 & $1.521-9.429$ \\
during pregnancy & & & & & \\
Mothers 25(OH)D & -0.127 & 36.355 & $<0.001$ & 0.881 & $0.845-0.918$ \\
Mothers PTH & 0.058 & 7.142 & 0.008 & 1.059 & $1.015-1.105$ \\
Mothers age & 0.005 & 0.007 & 0.935 & 1.005 & $0.899-1.122$ \\
Gestational times & 0.045 & 0.042 & 0.838 & 1.046 & $0.679-1.611$ \\
Delivery times & 0.191 & 0.196 & 0.658 & 1.210 & $0.520-2.815$ \\
CB calcium & -1.545 & 7.189 & 0.007 & 0.213 & $0.069-0.660$ \\
CB phosphorus & 1.109 & 3.127 & 0.077 & 3.032 & $0.887-10.370$ \\
CB ALP & -0.001 & 0.096 & 0.756 & 0.999 & $0.994-1.005$ \\
CB PTH & -0.077 & 1.172 & 0.279 & 0.926 & $0.806-1.064$ \\
& & & & &
\end{tabular}

CB for cord blood, PTH for parathyroid hormone; ALP for alkaline phosphatase.

associated with an increased prevalence of neonatal and maternal hypovitaminosis D during pregnancy $(20,21)$.

Our study found that neonatal vitD had a positive correlation with maternal vitD, so did neonatal calcium and phosphorus, which was consistent with cardinal features in fetal vitD metabolic system $(22,23)$. For neonates, maternal-fetal transport is the main source of vitD, and maternal vitD reserves during pregnancy determine the level of vitD in cord blood. Maternal hypovitaminosis D significantly increased the risk of neonatal vitD deficiency $(14,15,18)$ and poor development of neonatal bone mineralization at birth, also observed in this study. The $25(\mathrm{OH}) \mathrm{D}$ concentrations in cord blood were $60-70 \%$ of their mothers' values, but optimal cord blood $25(\mathrm{OH}) \mathrm{D}$ is not known $(23,24)$.

Hypovitaminosis D in many neonates may not be clinically relevant unless there is associated biochemical evidence of vitamin $\mathrm{D}$ deficiency (25). In this study, there was also a tendency to higher serum ALP and PTH levels in neonates with hypovitaminosis $\mathrm{D}$ than the values in normal-25(OH)D group. It is similar to findings in early or asymptomatic cases of vitamin D deficiency rickets $(25,26)$. Bone metabolic activity as measured by ALP levels was occasionally increased in patients with low 25(OH)D levels, consistent with previous studies (27-29). VitD plays an important role in the process of fetal growth, and cooperates with PTH to maintain calcium homeostasis. Longterm vitD deficiency can lead to increased PTH concentrations
$(30,31)$. PTH is expressed in the placenta, regulates the placental expression of genes involved in the transfer of calcium and other solutes, and may directly stimulate placental calcium transfer (32). Despite many adaptations in the vitD-calcium metabolic system during pregnancy, the inverse relationship between $25(\mathrm{OH}) \mathrm{D}$ and PTH is retained, or only slightly weakened (33). In our study, neonates with hypovitaminosis D had an increase of PTH concentrations - though lower than the normal adult range, which might result from an intrauterine adaptive up-regulation of fetal PTH, as a result of maternal-fetal hypovitaminosis D, to maintain adequate calcium supply for the fetus development $(34,35)$. Besides, it has been previously reported that there was no correlation between $25(\mathrm{OH}) \mathrm{D}$ and PTH in cord blood $(36,37)$, indicating that the well documented increase of PTH in adults with secondary hyperparathyroidism, is not evident in neonates after birth, due to temporary suppression of PTH (35). Thus, PTH levels in cord blood could be lower than the normal adult range as long as no hypocalcemia happened $(35,38)$, in the condition of suppression by active placental calcium transport (39). Increased PTH levels in mothers and decreased cord blood calcium levels could indicate neonatal risk of vitD deficiency. Studies on the threshold of ALP and PTH under subclinical hypovitaminosis D are limited and variable (40). Further studies are necessary to evaluate the magnitude of neonatal ALP and $\mathrm{PTH}$ variation under circumstances of vitamin D status at birth.

Our results demonstrated a seasonal variation in $25(\mathrm{OH}) \mathrm{D}$. The vitD levels in cord blood and mothers were highest in summer and lowest in winter. Such findings may arise from increases in body surface exposure to sun during the summer. Seasons at sampling (autumn/winter) were reported as factors related to deficient $25(\mathrm{OH}) \mathrm{D}$ concentrations (41). Decreases in time spent outdoors, skin pigmentation, coverage and aging can all lead to insufficient vitD production (42-44). Increasing casual sun exposure for reaching the optimal serum 25(OH)D levels has been recommended (45). However, as excessive UV radiation is a carcinogen, it might be worth obtaining additional vitamin $\mathrm{D}$ from foods or supplements (3).

Our finding confirms that the main determinant of the vitamin $\mathrm{D}$ level in a neonate is the vitamin $\mathrm{D}$ level of the mother (46). The risk of neonatal vitD deficiency was increased almost nine-times in mothers who did not take vitD supplements during pregnancy. Strategies should be developed to prevent maternal and neonatal vitamin D deficiency. Daily prenatal vitamin D supplementation should be promoted, particularly in the 3rd trimester when the majority of placental vitamin $\mathrm{D}$ transfer to the fetus occurs, with the women who have insufficient sunlight 
exposure taken into account (39). The current recommended intake for vitamin D during pregnancy is at least $600 \mathrm{IU} /$ day of vitamin D by both the Endocrine Society (4) and the Institute of Medicine (47). And Hollis's study showed that vitamin D supplementation of 4,000 IU/day for pregnant women was safe and most effective (12). With the addition of calcium supplement in pregnancy, mothers had higher maternal concentrations of vitD (48), which had a positive effect on neonatal vitD levels (49). Supplementation of $400 \mathrm{IU} /$ day $(10 \mu \mathrm{g})$ of vitD is adequate to prevent rickets and recommended for all infants from birth to 12 months of age, independent of their mode of feeding (13).

This study had several limitations. First, maternal data that may correlate with neonatal vitD levels at birth, such as the pre-pregnancy body mass index, skin color, and sun exposure during pregnancy were not collected. However, such limitations were unlikely to affect the vitD levels of neonates at birth (50). Secondly, our analyses lacked a detailed evaluation of dietary protein and fat intake as potential food sources of vitD. Finally, the sample size from Naqu was relatively small, compared to that from Shenyang and other related studies, which may have biased the statistical analysis.

\section{CONCLUSIONS}

In conclusion, this study reported results from a prospective maternal-neonatal cohort study between the Naqu plateau and Shenyang non-plateau area, that mainly focused on neonatal vitD deficiency. The study demonstrated a high prevalence of vitD deficiency in mothers and neonates in both populations, which was purely derived from the $>95 \%$ of individuals from Naqu and 50\% from Shenyang who had vitD deficiency/insufficiency, and revealed the particularly higher risk of such deficiency in individuals from Naqu, Tibet. VitD supplementation should be provided to pregnant women with risk factors based on their place of residence and lifestyle, such as plateau areas. Our study also provided data on the specificpopulation characteristics for developing recommendations to prevent neonatal vitD deficiency in ultrahigh altitude regions.

\section{REFERENCES}

1. Gluckman PD, Hanson MA, Cooper C, Thornburg KL. Effect of in utero and early-life conditions on adult health and disease. N Engl J Med. (2008) 359:61-73. doi: 10.1056/NEJMra0708473

2. Özdemir AA, Ercan Gündemir Y, Küçük M, Yildiran Sarici D, Elgörmüş Y, Çag Y, et al. Vitamin D deficiency in pregnant women and their infants. J Clin Res Pediatr Endocrinol. (2018) 10:44-50. doi: 10.4274/ jcrpe. 4706

3. De-Regil LM, Palacios C, Lombardo LK, Peña-Rosas JP. Vitamin D supplementation for women during pregnancy. Cochrane Database Syst Rev. (2016) 1:CD008873. doi: 10.1002/14651858.CD008873.pub3

4. Holick MF, Binkley NC, Bischoff-Ferrari HA, Gordon CM, Hanley DA, Heaney RP, et al. Evaluation, treatment, and prevention of vitamin D deficiency: an endocrine society clinical practice guideline.

\section{DATA AVAILABILITY STATEMENT}

All datasets generated for this study are included in the article/supplementary material.

\section{ETHICS STATEMENT}

The studies involving human participants were reviewed and approved by Ethics Committee of the Shengjing Hospital of China Medical University (Protocol Identification Number: 2017PS33K). Written informed consent from the participants' legal guardian/next of kin was not required to participate in this study in accordance with the national legislation and the institutional requirements.

\section{INFORMED CONSENT}

The study involving human participants were reviewed and approved by Shengjing Hospital of China Medical University Ethics Committee (Shenyang, China). The study does not contain patients' personal information, fully protects the patients' privacy. The samples used in the study are all discarded samples after the clinical routine diagnosis and treatment, which has no impact on the routine diagnosis and treatment of patients. The patients do not conduct additional tests/checks due to participating in the study, and there is no harm to the patients, so we got through exemption from informed consent (Protocol Identification Number: 2017PS33K).

\section{AUTHOR CONTRIBUTIONS}

MY, XL, and JL: study conception and design. MY and XL: data acquisition. MY and JL: analysis and data interpretation. MY: drafting of the manuscript. JL: critical revision. All authors contributed to the article and approved the submitted version.

\section{FUNDING}

This study was funded by Natural science foundation of Tibet autonomous region, XZ2017ZR-ZY024, 100,000 Yuan.

J Clin Endocrinol Metab. (2011) 96:1911-30. doi: 10.1210/jc.20110385

5. Holick MF. Vitamin D: a D-lightful solution for health. J Investig Med. (2011) 59:872-80. doi: 10.2310/JIM.0b013e31821 4ea2d

6. Holick MF, Chen TC, Lu Z, Sauter E. Vitamin D and skin physiology: a Dlightful story. J Bone Miner Res. (2007) 22:V28-33. doi: 10.1359/jbmr.07s211

7. Holick MF, Chen TC. Vitamin D deficiency: a worldwide problem with health consequences. Am J Clin Nutr. (2008) 87:1080S-6S. doi: 10.1093/ajen/87.4.1080S

8. Ponsonby AL, Lucas RM, Lewis S, Halliday J. Vitamin D status during pregnancy and aspects of offspring health. Nutrients. (2010) 2:389-407. doi: $10.3390 /$ nu2030389

9. Looker AC, Dawson-Hughes B, Calvo MS, Gunter EW, Sahyoun NR. Serum 25-hydroxyvitamin D status of adolescents and adults in two 
seasonal subpopulations from NHANES III. Bone. (2002) 30:771-7. doi: 10.1016/S8756-3282(02)00692-0

10. Alp H, Tekgündüz KS, Akkar MK. Maternal and cord blood vitamin D status in high-altitude pregnancy. J Matern Fetal Neonatal Med. (2015) 29:1-5. doi: $10.3109 / 14767058.2015 .1011119$

11. Norsang G, Ma L, Dahlback A, Zhuoma C, Tsoja W, Porojnicu A, et al. The vitamin D status among Tibetans. Photochem Photobiol. (2009) 85:1028-31. doi: 10.1111/j.1751-1097.2009.00552.x

12. Hollis BW, Johnson D, Hulsey TC, Ebeling M, Wagner CL. Vitamin $\mathrm{D}$ supplementation during pregnancy: double-blind, randomized clinical trial of safety and effectiveness. J Bone Miner Res. (2011) 26:2341-57. doi: $10.1002 /$ jbmr.463

13. Munns CF, Shaw N, Kiely M, Specker BL, Thacher TD, Ozono K. Global consensus recommendations on prevention and management of nutritional rickets. J Clin Endocrinol Metab. (2016) 85:394-415. doi: 10.1210/jc. 2015-2175

14. Zhuang XL, Zhu ZW, Zhu DB, Chen LQ, Zhao ZY, Shao J. Maternalneonatal vitamin D status and related factors. Chin J Pediatr. (2012) 50:498-503.

15. Wu JY, Zhou XJ, Hong JG. Relationship of $25(\mathrm{OH})$ D levels in cord and maternal peripheral blood. J Clin Pediatr. (2014) 32:1069-71.

16. Chen QZ, Gao YH, Department of Obstetrics, Guangzhou Women and Children Medical Centre. Changes of 25-hydroxy vitamin D levels in cord blood of small for gestational age and appropriate for gestational age newborns. Chin J Woman Child Health Res. (2016) 27:676-8.

17. Wang C, Gao J, Liu N, Yu S, Qiu L, Wang D. Maternal factors associated with neonatal vitamin D deficiency. J Pediatr Endocrinol Metab. (2019) 32:167-72. doi: 10.1515/jpem-2018-0422

18. Dovnik A, Mujezinović F, Treiber M, Pečovnik Balon B, Gorenjak M, Maver $\mathrm{U}$, et al. Seasonal variations of vitamin $\mathrm{D}$ concentrations in pregnant women and neonates in Slovenia. Eur J Obstet Gynecol. (2014) 181:6-9. doi: 10.1016/j.ejogrb.2014.07.019

19. Merewood A, Mehta SD, Grossman X, Chen TC, Mathieu JS, Holick MF, et al. Widespread vitamin D deficiency in urban Massachusetts newborns and their mothers. Pediatrics. (2010) 125:640-7. doi: 10.1542/peds.2009-2158

20. Jiang L, Xu J, Pan S, Xie E, Hu Z, Shen H. High prevalence of hypovitaminosis D among pregnant women in southeast China. Acta Paediatr. (2012) 101:1924. doi: 10.1111/j.1651-2227.2011.02557.x

21. Mendes MM, Darling AL, Hart KH, Morse S, Murphy RJ, Lanham-New SA. Impact of high latitude, urban living and ethnicity on 25-hydroxyvitamin D status: a need for multidisciplinary action? J Steroid Biochem Mol Biol. (2019) 188:95-102. doi: 10.1016/j.jsbmb.2018.12.012

22. Bhalala U, Desai M, Parekh P, Mokal R, Chheda B. Subclinical hypovitaminosis D among exclusively breastfed young infants. Indian Pediatr. (2007) 44:897-901.

23. Waiters B, Godel JC, Basu TK. Perinatal vitamin D and calcium status of northern Canadian mothers and their newborn infants. J Am Coll Nutr. (1999) 18:122-6. doi: 10.1080/07315724.1999.10718839

24. Hollis BW, Wagner CL. Assessment of dietary vitamin D requirements during pregnancy and lactation. Am J Clin Nutr. (2004) 79:717-26. doi: $10.1093 /$ ajen/79.5.717

25. Zeghoud F, Vervel C, Guillozo H, Walrant-Debray O, Boutignon H, Garabédian M. Subclinical vitamin D deficiency in neonates: definition and response to vitamin D supplements. Am J Clin Nutr. (1997) 65:771-8. doi: 10.1093/ajcn/65.3.771

26. Dawodu A, Agarwal M, Hossain M, Kochiyil J, Zayed R. Hypovitaminosis $\mathrm{D}$ and vitamin $\mathrm{D}$ deficiency in exclusively breast-feeding infants and their mothers in summer: a justification for vitamin D supplementation of breast-feeding infants. J Pediatr. (2003) 142:0-173. doi: $10.1067 / \mathrm{mpd}$. 2003.63

27. Maghbooli Z, Hossein-Nezhad A, Shafaei AR, Karimi F, Madani FS, Larijani B. Vitamin D status in mothers and their newborns in Iran. BMC Pregnancy Childbirth. (2007) 7:1-6. doi: 10.1186/14712393-7-1

28. Gessner BD, Plotnik J, Muth PT. 25-Hydroxyvitamin D levels among healthy children in Alaska. J Pediatr. (2003) 143:434-7. doi: $10.1067 /$ S0022-3476(03)00410-4
29. Glerup H, Mikkelsen K, Poulsen L, Hass E, Overbeck S, Thomsen $\mathrm{J}$, et al. Commonly recommended daily intake of vitamin D is not sufficient if sunlight exposure is limited. J Intern Med. (2000) 247:260-8. doi: 10.1046/j.1365-2796.2000.00595.x

30. Houghton LA, Szymlek-Gay EA, Gray AR, Ferguson EL, Deng X, Heath AL. Predictors of vitamin D status and its association with parathyroid hormone in young New Zealand children. Am J Clin Nutr. (2010) 92:69. doi: $10.3945 /$ ajen.2009.29055

31. Specker B. Vitamin D requirements during pregnancy. Am J Clin Nutr. (2004) 80:1740S. doi: 10.1093/ajcn/80.6.1740S

32. Simmonds CS, Karsenty G, Karaplis AC, Kovacs CS. Parathyroid hormone regulates fetal-placental mineral homeostasis. J Bone Miner Res. (2010) 25:594-605. doi: 10.1359/jbmr.090825

33. Kiely M, Hemmingway A, O'Callaghan, Karen M. Vitamin D in pregnancy: current perspectives and future directions. Ther Adv Musculoskelet Dis. (2017) 9:145-54. doi: 10.1177/1759720X17706453

34. Wagner CL, Hollis BW, Kotsa K, Fakhoury H, Karras SN. Vitamin D administration during pregnancy as prevention for pregnancy, neonatal and postnatal complications. Rev Endocr Metab Disord. (2017) 18:307-22. doi: 10.1007/s11154-017-9414-3

35. Karras SN, Koufakis T, Antonopoulou V, Goulis DG, Annweiler C, Pilz S, et al. Characterizing neonatal vitamin D deficiency in the modern era: a maternalneonatal birth cohort from Southern Europe. Steroid Biochem Mol Biol. (2020) 198:105555. doi: 10.1016/j.jsbmb.2019.105555

36. Bowyer L, Catling-Paull C, Diamond T, Homer C, Davis G, Craig ME. Vitamin D, PTH and calcium levels in pregnant women and their neonates. Clin Endocrinol (Oxf). (2008) 70:372-7. doi: 10.1111/j.1365-2265.2008. 03316.x

37. Young BE, McNanley TJ, Cooper EM, McIntyre AW, Witter F, Harris ZL, et al. Maternal vitamin D status and calcium intake interact to affect fetal skeletal growth in utero in pregnant adolescents. Am J Clin Nutr. (2012) 95:1103-12. doi: $10.3945 /$ ajcn.111.023861

38. Cao YM. Study on Vitamin D Nutritional Status and Related Factors of Perinatal Women and Newborns in Suzhou. Suzhou: Suzhou University (2013).

39. Bass JK, Chan GM. Calcium nutrition and metabolism during infancy. Nutrition. (2006) 22:1057-66. doi: 10.1016/j.nut.2006.05.014

40. Hatun S, Ozkan B, Orbak Z, Doneray H, Cizmecioglu F, Toprak D, et al. Vitamin D deficiency in early infancy. J Nutr. (2005) 135:279-82. doi: $10.1093 / \mathrm{jn} / 135.2 .279$

41. Karras SN, Anagnostis P, Annweiler C, Naughton DP, Petroczi A, Bili E, et al. Maternal vitamin D status during pregnancy: the Mediterranean reality. Eur J Clin Nutr. (2014) 68:864-9. doi: 10.1038/ejcn.2014.80

42. Holvik K, Meyer HE, Haug E, Brunvand L. Prevalence and predictors of vitamin $\mathrm{D}$ deficiency in five immigrant groups living in Oslo, Norway: the Oslo Immigrant Health Study. Eur J Clin Nutr. (2005) 59:57-63. doi: $10.1038 /$ sj.ejen. 1602033

43. Van der Meer IM, Karamali NS, Boeke AJ, Lips P, Middelkoop BJ, Verhoeven I, et al. High prevalence of vitamin D deficiency in pregnant non-Western women in The Hague, Netherlands. Am J Clin Nutr. (2006) 84:350-3. doi: 10.1093/ajen/84.2.350

44. Kaushal M, Magon N. Vitamin D in pregnancy: a metabolic outlook. Indian J Endocrinol Metab. (2013) 17:76-82. doi: 10.4103/2230-8210. 107862

45. Holick MF. Too little vitamin D in premenopausal women: why should we care? Am J Clin Nutr. (2002) 76:3-4. doi: 10.1093/ajcn/76.1.3

46. Halicioglu O, Aksit S, Koc F, Akman SA, Albudak E, Yaprak I, et al. Vitamin $\mathrm{D}$ deficiency in pregnant women and their neonates in spring time in western Turkey. Paediatr Perinat Epidemiol. (2012) 26:53-60. doi: 10.1111/j.1365-3016.2011.01238.x

47. Ross AC, Manson JE, Abrams SA, Aloia JF, Brannon PM, Clinton SK, et al. The 2011 report on dietary reference intakes for calcium and vitamin $\mathrm{d}$ from the institute of medicine: what clinicians need to know. Obstet Gynecol Surv. (2011) 66:356-7. doi: 10.1097/OGX.0b013e3182 2c197a

48. Park H, Brannon PM, West AA, Yan J, Jiang X, Perry CA, et al. Maternal vitamin D biomarkers are associated with maternal and fetal bone turnover among pregnant women consuming controlled 
amounts of vitamin D, calcium, and phosphorus. Bone. (2017) 95:183-91. doi: 10.1016/j.bone.2016.12.002

49. Wang $\mathrm{Y}, \mathrm{Li} \mathrm{H}$, Zheng M, Wu Y, Zeng T, Fu J, et al. Maternal vitamin D deficiency increases the risk of adverse neonatal outcomes in the Chinese population: a prospective cohort study. PLoS ONE. (2018) 13:e0195700. doi: 10.1371/journal.pone.0195700

50. Marshall I, Mehta R, Ayers C, Dhumal S, Petrova A. Prevalence and risk factors for vitamin D insufficiency and deficiency at birth and associated outcome. BMC Pediatr. (2016) 16:208. doi: 10.1186/s12887-0160741-4
Conflict of Interest: The authors declare that the research was conducted in the absence of any commercial or financial relationships that could be construed as a potential conflict of interest.

Copyright $(0) 2020 \mathrm{Yu}$, Liu and Li. This is an open-access article distributed under the terms of the Creative Commons Attribution License (CC BY). The use, distribution or reproduction in other forums is permitted, provided the original author(s) and the copyright owner(s) are credited and that the original publication in this journal is cited, in accordance with accepted academic practice. No use, distribution or reproduction is permitted which does not comply with these terms. 